\title{
How Many Highly Skilled Foreign- Born are Waiting in Line for U.S. Legal Permanent Residence?
}

Guillermina Jasso

New York University

Vivek Wadhwa

Gary Gereffi

Duke University

Ben Rissing

Massachusetts Institute of Technology

Richard Freeman

Harvard University

While the United States welcomes foreign-born students and trainees and, less warmly, temporary workers such as H-1B visa holders, it places an array of requirements, obstacles, and delays upon persons who would like to make the U.S. their permanent home. The number of people in the queue for legal permanent residence (LPR) is, however, difficult to ascertain. This paper estimates the number of highly skilled foreign-born persons waiting for LPR via the three main employment-based categories, separately by whether they are living in the United States or abroad, as well as the number of family members. We find that as of the end of FY 2006 there were

\footnotetext{
${ }^{1}$ Earlier versions of portions of this paper were presented at meetings of the American Sociological Association and the Population Association of America; at the NBER-Sloan Workshop on Foreign-Born Scientists and Engineers, the CIDE-Universidad Iberoamericana-Georgetown University Workshop on Migration and Remittances, and the Applied Demography Conference; and at colloquia at Pennsylvania State University and Academia Sinica. We are grateful to participants at those meetings and especially to Joseph $\mathrm{M}$. Costanzo, Cynthia Feliciano, Filiz Garip, Grace Kao, Eric Larson, B. Lindsay Lowell, Fernando Riosmena, Robert Warren, the anonymous referees and the Editor for many valuable comments and suggestions. We also gratefully acknowledge the intellectual and financial support of the Kauffman Foundation, Duke University, Harvard University, Massachusetts Institute of Technology, and New York University.
} 
about half a million employment-based principals awaiting LPR in the United States, together with over half a million family members, plus over 125 thousand principals and family members waiting abroad. These numbers dwarf the visas available annually $-120,120$ plus any not used in the family preferences - suggesting that the long delays in gaining legal permanent residence are a visa number problem, not an administrative processing problem, as many believe. The backlog thus cannot be eliminated without a large change in public policy. The delay in gaining legal permanent residence could contribute to the decision of many highly skilled foreign-born to leave the United States.

\section{INTRODUCTION}

Every year approximately one million persons are admitted to legal permanent residence (LPR) in the United States. Over half of them are already residing in the U.S. and adjust their status from a legal temporary visa or from undocumented status. For example, during the 10-year period from 1996 to 2005, the number of persons who adjusted their status exceeded that of new arrivals in all but 3 years (1998, 1999, and 2003 - years in which administrative and staffing conditions produced large backlogs in immigrant visa processing in offices of the U.S. Immigration and Naturalization Service [INS] and subsequently U.S. Citizenship and Immigration Services [USCIS]). Over the entire period, the proportion of persons admitted to LPR who adjusted their status was 55.8 percent. The proportion increased to 64.6 percent in 2006 and remained above the long-term average in 2007 at 59 percent and in 2008 at 57.9 percent.

Despite increased national concern with immigration, little is known about the adjustee subset of new LPRs or the people waiting in line for LPR in the United States. Readily available official statistics on immigrants became increasingly sparse in the late 1990s and 2000s. Indicative of the reduction in statistics, the annual government report on immigration - submitted by INS and subsequently the Department of Homeland Security (DHS) - fell from 274 pages plus appendices in 2000 to 195 
pages plus appendices in 2003 to 124 pages and no appendices in 2005 to 104 pages and no appendices in $2007 .^{2}$

Vital elements of the annual reports have disappeared. The number of tables on new immigrants fell from 21 in 1992-1998 to 11 in 2003 and 2004, then increased to 12 (plus four supplemental tables available on the website of the Office of Immigration Statistics). The announcement of public-use microdata on the annual immigrant cohorts disappeared in 1997. Analysis and discussion of the matched immigrantnaturalization cohorts, a feature since 1991, disappeared in 1998. Traditionally, the INS and subsequently DHS published tabulations in the Statistical Yearbook which provided the immediately preceding nonimmigrant category of new adjustee LPRs and the year of admission to that nonimmigrant category (Tables 9 and 10 in the Yearbooks from 1986 to 1991 and Tables 10 and 11 in the period 1992-2002). Both tables, which provided insight into the pre-LPR queue - the first (Table 9/10), for example, showing that new legal permanent residents include persons who were not only illegal but had "Entered without inspection" - disappeared in 2003. Since then the Yearbook includes only the breakdown of adjustees and new arrivals for every immigrant visa category (in Table 7). Text, which had been incorporated to guide readers through tables in 1986, disappeared in 2004. Reports no longer include a transmittal letter signifying their importance.

Meanwhile, at the Department of State, the annual counts of persons in the queue for numerically limited family and employment immigrant visas, published annually in the years 1980-1995, and again in 1997, disappeared after 1997, except for a tantalizing look at the family waiting lists as of January 2009.

As the United States considers immigration policy, information on the number of persons in the pre-LPR queue is critically important. The close link between the size of the queue and visa allocation design has been understood at least since the days of the U.S. Select Commission on Immigration and Refugee Policy (1981:352-456, esp. 377), and the theme recurs in the second Triennial Comprehensive Report on

\footnotetext{
${ }^{2}$ The annual statistical reports were titled Annual Report of the Immigration and Naturalization Service until 1977, Statistical Yearbook of the Immigration and Naturalization Service in the years 1978-2001, and Yearbook of Immigration Statistics for the years since 2002. The 2002 Yearbook was the first published after the Immigration and Naturalization Service was incorporated into the new Department of Homeland Security on March 1, 2003.
} 
Immigration (1999), mandated by the Immigration Reform and Control Act of 1986, and the U.S. General Accounting Office (1989:2,4,38-42) report assessing the expected effects on visa waiting lists of the proposed legislation that led to the Immigration Act of 1990. Such information provides insight on the sustainability of the current visa allocation system, with implications for the productivity of those in the queue as well as the subsequent well-being of new immigrants and their attachment to the United States. Moreover, a nontrivial fraction of the queue may be included in the estimates of illegal residents (Warren, 2003:4,11-12).

The size of the employment-based portion of the pre-LPR queue is a pressing question and one for which there is no official answer. As the U.S. CIS Ombudsman (2007:13) observed in the 2007 annual report to Congress, submitted in June 2007:

Failing to correct the system annually results in hundreds, if not thousands, of wasted
hours by all levels of USCIS leadership in trying to account for an often asked question
by Congress, the Ombudsman, stakeholders, and others: "Exactly how many employment-
based green card applications does the agency have pending?" USCIS still cannot answer
that question today with certainty.

With little information publicly available, the challenge is thus to estimate the size of the pre-LPR queue. This paper focuses on the highly skilled pre-LPR queue. We develop a framework that combines information from official statistics of the Departments of Homeland Security, Labor, and State, and we obtain estimates for the size of the queue at the end of Fiscal Year 2006.

As well, we provide additional insight on highly skilled immigration with information from the New Immigrant Survey, the first nationally representative longitudinal study of new legal immigrants $<$ http://nis.princeton.edu>. The baseline round of this survey collected extensive data on the immigrant cohort of 2003 - for which it interviewed 8,573 adult immigrants on average four-and-a-half months after admission to LPR. These data show, for example, that in 2003 the average time to LPR since filing of the first application that started the visa process was 4.3 years for adjustee employment principals; that the process of applying for an LPR visa is sufficiently arduous that approximately 22.4 percent of adjustee employment principals became depressed as a result of the visa process; and that 34.5 percent of adjustee employment principals either plan to leave the U.S. or are uncertain about remaining. 
It is often thought that the long delays in getting an immigrant visa are due to processing problems. Indeed, in July 2007 a group of highly skilled foreign-born in the United States seeking to speed the process of admission to LPR sent thousands of flowers to the director of Citizenship and Immigration Services (Bernstein, 2007). However, even if processing became lightning-fast, long delays would remain, because employmentbased visas are numerically restricted and the demand outstrips the supply.

\section{FRAMEWORK FOR ESTIMATING THE HIGHLY SKILLED PRE-LPR QUEUE}

\section{Defining the Highly Skilled Pre-LPR Queue}

U.S. immigration law provides 140,000 visas annually for employment principals in five categories and their spouses and minor children, plus any visas not used the previous year in the family categories, plus, in some years, additional visas "recaptured" by statute. Thus, the worldwide ceilings have exceeded 140,000 in every year since FY 1999 - for example, 143,949 in $2006,147,148$ in 2007 , and 162,704 in $2008 .^{3}$

The first task in defining the highly skilled pre-LPR queue is to define the visa categories of interest. The natural focus is the set of principals in the first, second, and third employment-based immigrant visa categories - EB-1, EB-2, and EB-3 - minus the small subcategory of EB-3 reserved for "other workers." The fourth and fifth employment categories are more peripheral; the fourth is for "special immigrants," including ministers and other religious workers as well as juvenile court dependents, while the fifth is for investors. Numerically, EB-4 and EB-5 are small; they receive only 14.2 percent of the total number of employment visas, and this number is not fully used. ${ }^{4}$

We cannot, however, remove from the EB-3 category the subcategory for the less-skilled "other workers" because the information available for estimating the pre-LPR population pertains to entire categories and does not permit disaggregation by subcategory. The "other workers" sub-

\footnotetext{
${ }^{3}$ The annual ceilings are calculated by the Department of State and reported in the Visa Bulletin (in the September issue) as well as in DHS reports, such as Monger and Rytina (2009:6).

${ }^{4}$ For example, in FY 2006, of the 159,081 immigrants admitted with employment visas, only 10,288 visas - or 6.5 percent - went to these categories. The corresponding figures for FYs 2007 and 2008 are 6,287 (3.88\%) and 10,884 (6.54\%).
} 
category in any case is small. Initially given a separate ceiling of 10,000 visas a year (for both principals and family members), its limit has been reduced to 5,000 since FY 2002, under the provisions of the Nicaraguan and Central American Relief Act (NACARA).

Accordingly, we focus on principals in the first, second, and third employment-based visa categories - referred to in this paper as "employment principals" and described in Table 1. These three categories each receive 28.6 percent of the worldwide employment visa allocation - 85.8 percent together. They start from a base of 120,120 visas a year but may

TABLE 1

Categories and Subcategories for Principals in the First Three Employment Preference Categories (EB-1, EB-2, and EB-3) under the U.S. Immigrant Visa Allocation System Prescribed by the Immigration and Nationality Act, as Amended by the Immigration Act of 1990, Effective FY 1992

\begin{tabular}{lll}
\hline \hline Visa codes & & \\
Arrival $\quad$ Adjustee & Description
\end{tabular}

A. Employment first preference (EB-1) - priority workers

The number of visas available for both principals and family members is $28.6 \%$ of the worldwide employment-based visa ceiling, plus any numbers not required by EB- 4 and EB-5.

$\begin{array}{lll}\text { E11 } & \text { E16 } & \text { Aliens with extraordinary ability } \\ \text { E12 } & \text { E17 } & \text { Outstanding professors or researchers } \\ \text { E13 } & \text { E18 } & \text { Multinational executives or managers }\end{array}$

B. Employment second preference (EB-2)

The number of visas available for both principals and family members is $28.6 \%$ of the worldwide employment-based visa ceiling, plus any numbers not required by EB-1.

E21 E26 Professionals with advanced degrees or aliens of exceptional ability

C. Employment third preference (EB-3)

The number of visas available for both principals and family members is $28.6 \%$ of the worldwide employment-based visa ceiling, plus any numbers not required by EB-1 and EB-2. The total number of visas available for the $\mathrm{EW}$ other workers and their family members is 10,000 , but, under provisions of the Nicaraguan and Central American Relief Act, as amended, the limit has been reduced to 5,000 since FY 2002.

\begin{tabular}{lcl} 
E31 & E36 & Skilled workers \\
E32 & E37 & Professionals with baccalaureate degrees \\
EW3 & EW8 & Other workers \\
\hline
\end{tabular}

Notes:

1. The worldwide allocation to all five employment-based preference categories is 140,000 plus any visas not used in the previous year by the family-based preference categories. Additionally, employment-based visas not used due to processing delays are sometimes "recaptured" by statute, thus increasing the worldwide limit. For example, the worldwide ceiling for employment-based visas was 143,949 in 2006, 147,148 in 2007, and 162,704 in 2008 .

2. Substantively, the "other workers" subcategory of EB-3 should be excluded in a discussion of highly skilled prospective immigrants. Unfortunately, the data sources to be used in order to estimate the queue do not permit disaggregation by subcategory.

3. Each category also provides visas for the spouses and minor children of the principals; those visas have distinct codes. 
TABLE 2

EB-1, EB-2, and EB-3 Immigrant Principals in Fiscal Years 2006, 2007, and 2008

\begin{tabular}{lrrrrrrrr}
\hline \hline & \multicolumn{2}{c}{ FY 2006 } & & \multicolumn{2}{c}{ FY 2007 } & & \multicolumn{2}{c}{ FY 2008 } \\
\cline { 2 - 3 } Visa & Arrival & Adjustee & & Arrival & Adjustee & & Arrival & Adjustee \\
\hline EB-1 principal & 1,969 & 13,101 & & 1,009 & 9,958 & & 546 & 14,638 \\
Extraordinary ability & 670 & 2,669 & & 445 & 1,798 & & 313 & 2,948 \\
Professors/researchers & 121 & 2,830 & & 35 & 2,226 & & 22 & 4,252 \\
Multinational executives & 1,178 & 7,602 & & 529 & 5,934 & & 211 & 7,438 \\
EB-2 principal & 373 & 10,231 & & 460 & 21,843 & & 481 & 34,054 \\
EB-3 principal & 9,885 & 30,844 & & 5,328 & 31,211 & & 1,613 & 18,983 \\
Schedule A workers & 8,928 & 4,295 & & 3,200 & 531 & & 6 & 6 \\
Skilled workers & 640 & 20,874 & & 1,531 & 16,434 & & 1,022 & 9,089 \\
Baccalaureate & 170 & 3,319 & & 505 & 11,860 & & 456 & 8,105 \\
Other workers & 147 & 2,356 & & 92 & 2,386 & & 129 & 1,783 \\
All EB-1, EB-2, EB-3 & 12,227 & 54,176 & & 6,797 & 63,012 & & 2,640 & 67,675 \\
principals & & & & & & & \\
All immigrants & 447,016 & 819,248 & & 431,368 & 621,047 & & 466,558 & 640,568 \\
\hline
\end{tabular}

Note: Figures compiled from the Department of Homeland Security Yearbook of Immigration Statistics for FYs 2006-2008.

acquire more visas not only when the worldwide ceiling exceeds 140,000 or visas are "recaptured" but also when visas are unused in EB-4 and EB-5. Thus, the visa allocation for the first three employment categories averaged 151,267 in Fiscal Years 2006-2008 (Visa Bulletin), and actual immigration averaged 153,436 (Monger and Rytina 2009:3). ${ }^{5}$

Table 2 shows the number of principals in each category/subcategory, separately by whether they were new arrivals or adjustees. As shown, employment principals are much more likely to adjust status than their cohortmates with other visas - 81.6 percent, 90.3 percent, and 96.2 percent in Fiscal Years 2006-2008, respectively, versus 64.6 percent, 59 percent, and 57.9 percent in the cohorts overall. These numbers are even more striking when one considers that an unknown fraction of the new arrivals are applicants already resident in the United States who exercise the option for consular processing.

The second task in defining the highly skilled pre-LPR queue is to specify what it means to be waiting in line for a visa. The visa process lasts

${ }^{5}$ For example, the American Competitiveness in the 21st Century Act of 2000 recaptured 130,137 employment visas which had been unused in 1999-2000 and made them available to EB-1, EB-2, and EB-3. The Real ID Act of 2005 recaptured 50,000 unused employment visas from the period 2001-2004, allocating them to workers in Schedule A occupations designated by the Department of Labor (chiefly nurses, physical therapists, and aliens of exceptional ability in the arts, sciences, or performing arts). The recaptured numbers were used mainly in FY 2005-2007, with a few in the Schedule A subset in FY 2008 . 
from the filing of the first application to the date of admission to LPR. Applicants for numerically limited visa cases are assigned a "priority date," defined as the date of the filing of the first application in the case. We thus define the population in the queue as the population with a priority date.

\section{Visa Process for Highly Skilled Employment-Visa Applicants}

For EB-2 and EB-3 cases, the first application is the Application for Permanent Employment Certification (ETA Form 9089, formerly Form 750), filed by the employer with the Department of Labor. For EB-1 cases, the first application is the Petition for Alien Worker (I-140), filed by the employer with USCIS. EB-2 and EB-3 cases file the I-140 after labor certification is obtained (except as noted below).

There are two main exceptions to the general filing requirements for labor certification and the I-140. One is that self-petition on the I-140 is permitted for one subcategory of EB-1 cases (the subcategory of persons with "extraordinary ability in the sciences, arts, education, business, or athletics which has been demonstrated by sustained national or international acclaim and whose achievements have been recognized in the field through extensive documentation" shown in Table 1) and one subset of EB-2 cases (those who obtain a national interest waiver). The other exception is that if the prospective immigrant will be employed in a Schedule A Group I or II occupation, the employer does not submit Form 9089 to the Department of Labor but instead submits it with the I-140 and all supporting documentation to USCIS.

Persons with temporary visas in the U.S. can file for adjustment of status if the visa for which they qualify is immediately available. In the employment sphere, this means that the visa category must be "current," in State Department parlance. In this case, prospective immigrants submit the Application to Register Permanent Residence or Adjust Status (I-485). ${ }^{6}$

The classical sequence of steps in the visa process for a prospective employment-based immigrant already in the United States is, first, file for labor certification (if needed); second, upon granting of labor certification, file the I-140; and third, upon approval of the I-140, file the I-485 for adjustment of status if a visa number is available (or as

${ }^{6}$ At the time the I-140 is filed, the petitioner (employer or self, as discussed above) may indicate that the prospective immigrant elects consular processing even if already in the United States. 
soon as it becomes available). However, as noted above, if the prospective immigrant will be employed in a Schedule A Group I or II occupation, then Form 9089 and the I-140 are filed jointly with USCIS. Moreover, for the past several years (since July 31, 2002) it has been permitted to file the I-140 and the I-485 at the same time a process known as concurrent filing - provided, of course, that a visa is available.

\section{Two Types of Visa Wait: Visa Number Wait and Visa Processing Wait}

The wait for an immigrant visa consists of two kinds of waiting times: waiting for a numerically limited visa (i.e., a "visa number"), which we will call the "visa number wait"; and waiting for the visa processing (associated with all three applications), which we will call the "visa processing wait." It may happen that visa processing for the labor certification and the I-140 is completed before the visa number becomes available, and for such cases all the experience of visa processing delay pertains to the I-485. Alternatively, it may happen that a visa number is available but there are delays at each step, a delay for processing the labor certification and a subsequent delay in processing the I-140, which in this case can be filed concurrently with the I-485. When demand exceeds the supply of visas, the applicant may be stranded in the queue after approval of the I- 140 .

\section{Remarks on Estimating the Highly Skilled Pre-LPR Queue in the United States}

Our objective is to estimate the size of the population who (1) have a priority date, (2) are in line for a principal visa in EB-1, EB-2, or EB-3, and (3) are in the United States.

In principle, it would appear easy to construct an electronic data base with a record for each such person in the visa process, and to store all relevant information such as origin country, immigrant visa category, priority date, etc., as has been proposed by the U.S. CIS Ombudsman (2007:35). Indeed, any of the information technology firms involved in the petitioning for workers could construct such a data set, but in practice there are many obstacles. For example, in the ideal data base the units 
would be persons - prospective immigrants - but part of the immigrant visa system is based on applications, not on persons. ${ }^{7}$

Additionally, while the labor certification and I-140 applications cover only principals, the I-485 covers both principals and family members. Further, the labor certification and I-140 cover applicants worldwide, while the I-485 covers only adjustment of status in the United States.

If administrative data systems improve so that the number of pending applications can be generated at the end of each fiscal year (if not the end of each quarter), separately by visa category and separately for principals and family members, and if the agencies publish the numbers pending, it will be possible to compare the estimates we present below with the true numbers - and, indeed, to construct a time series of the pre-LPR queue, which would enable tracking and analysis of fluctuations in the queue.

\section{Pre-LPR Queue and Future LPRs}

At each of the three steps (labor certification, I-140, I-485), the government denies some applications. Thus, at each step a fraction of the applicants in the pre-LPR queue disappear. Moreover, a prospective immigrant may also leave the employment-based pre-LPR queue if, for example, marriage to a U.S. citizen provides a faster route to LPR. Jasso, Rosenzweig, and Smith (2000) show that immigrants switch categories when it proves advantageous. Finally, some may become discouraged by the wait and accept opportunities in other countries. Thus, the number of future LPRs is smaller than the number in the pre-LPR queue.

\footnotetext{
${ }^{7}$ For example, sometimes more than one application can be filed for the same person. In the labor certification process, although an employer cannot file more than one application for the same worker for the same job opportunity, it is nonetheless possible for an employer to file more than one application for the same worker, if the applications pertain to different job opportunities, or for two employers to file for the same worker. It is also the case that more than one I-140 can be filed for the same prospective immigrant. And, finally, the prospective immigrant may file more than one I-485. An example of multiple I-485s involves married couples in which each spouse is the principal on a separate application.
} 


\section{ESTIMATION STRATEGY}

We develop a framework in which persons in the queue (i.e., persons who have a priority date) are classified into subsets corresponding to the stage of the visa process and the associated documents. In the case of employment principals who are waiting for LPR in the United States, the population is classified into six component subsets, as follows:

1. Those with a pending labor certification.

2. Those whose labor certification has been approved but whose I-140 employment petition is not yet filed.

3. Those with a pending I-140 who have not filed the I-485 adjustee petition (in most cases, because a visa number is not available).

4. Those with a pending I-140 and a pending I-485.

5. Those with an approved I-140 who have not filed the I-485 (again, in most cases, because a visa number is not available).

6. Those with an approved I-140 and a pending I-485. 8 ,9

Direct figures on each of these subsets would be an appropriate goal for data systems architects in the Departments of Labor, State, and Homeland Security. As noted above, the State Department provided for many years counts of approved eligible prospective immigrants waiting for numerically limited visas. Such counts could be used to approximate the fifth subset. Unfortunately, the State Department discontinued publication of these figures after $1997 .^{10}$

To guide estimation, we list in Table 3 the six subsets and examine four potential sources of information. The first piece of information is the number of pending labor certifications. This obviously exactly corresponds to the first subset, as indicated by "Y" for "Yes." The second is the

\footnotetext{
${ }^{8}$ Prospective immigrants who will work in Schedule A occupations are in subsets 3-6, as adjudication of the I-140 includes perusal of the Form 9089 and supporting documents.

${ }^{9}$ In the case of family preference visas, there would be three component subsets, paralleling subsets 3, 5, and 6 in the employment queue (with the I-140 replaced by Form I-130, Petition for Alien Relative).

${ }^{10}$ As noted above, totals for family preference categories were published in the March 2009 issue of the Visa Bulletin, a hopeful sign of possible things to come.
} 
TABLE 3

Six Subsets of the Employment-Based Pre-LPR Population, Four Information Sources, and Three Estimation Strategies

\begin{tabular}{|c|c|c|c|c|c|c|c|}
\hline \multirow[b]{2}{*}{$\begin{array}{l}\text { Subsets of pre-LPR } \\
\text { population }\end{array}$} & \multicolumn{4}{|c|}{ Sources of information } & \multicolumn{3}{|c|}{ Estimation strategies } \\
\hline & $\begin{array}{c}\text { (1) } \\
\text { Labor cert } \\
\text { pending }\end{array}$ & $\begin{array}{c}\text { (2) } \\
\text { I-140 } \\
\text { pending }\end{array}$ & $\begin{array}{c}\text { (3) } \\
\text { I-485 } \\
\text { pending }\end{array}$ & $\begin{array}{c}(4) \\
\text { I-140 } \\
\text { approved }\end{array}$ & $\begin{array}{r}(1) \\
+(3)\end{array}$ & $\begin{array}{r}(1) \\
+(2) \\
+(3)\end{array}$ & $\begin{array}{r}(1) \\
+(2) \\
+(4)\end{array}$ \\
\hline $\begin{array}{l}\text { 1. Labor certification } \\
\text { pending } \\
\text { 2. Labor certification } \\
\text { approved; I-140 } \\
\text { not yet filed }\end{array}$ & $Y$ & & & & $\mathrm{Y}$ & $\mathrm{Y}$ & $\mathrm{Y}$ \\
\hline $\begin{array}{l}\text { 3. I-140 pending; } \\
\text { I-485 not yet filed }\end{array}$ & & Y & & & & $\mathrm{Y}$ & Y \\
\hline $\begin{array}{l}\text { 4. I-140 pending; } \\
\text { I- } 485 \text { pending }\end{array}$ & & Y & Y & & Y & $Y Y$ & Y \\
\hline $\begin{array}{l}\text { 5. I-140 approved; } \\
\text { I-485 not yet filed }\end{array}$ & & & & Y & & & Y \\
\hline $\begin{array}{l}\text { 6. I-140 approved; } \\
\text { I-485 pending }\end{array}$ & & & $\mathrm{Y}$ & Y & $\mathrm{Y}$ & Y & $\mathrm{Y}$ \\
\hline \multicolumn{8}{|c|}{$\begin{array}{l}\text { Notes: Employment principals who will work in Schedule A occupations are in subsets } 3-6 \text {, as adjudication of } \\
\text { the I-140 includes perusal of the ETA Form } 9089 \text { and supporting documents. The second, third, and } \\
\text { fourth sources of information each capture two subsets of the pre-LPR population but cannot distinguish } \\
\text { between them. Information on pending labor certifications pertains to employment principals in EB-2 } \\
\text { and EB-3. Information on pending and approved I-140s pertains to employment principals in EB-1, } \\
\text { EB-2, and EB-3. Information on pending I- } 485 \text { s pertains to all prospective immigrants (both principals } \\
\text { and family members) in both employment- and family-based visa categories. The I-140 and I- } 485 \text { infor- } \\
\text { mation is available for Fiscal Years } 1992-2006 \text { from the U.S. Citizenship and Immigration Services Per- } \\
\text { formance Analysis System (U.S. CIS Ombudsman } 2007: 113-114 \text { ). Information on the I-140 and I-485 } \\
\text { pending applications is as of the end of the fiscal year; information on I-140 approvals pertains to } \\
\text { approvals during the fiscal year. Thus, the fifth and sixth subsets cannot be approximated solely from } \\
\text { the I-140 approval information but require building up the stock of persons with approved I-140s who } \\
\text { either have not filed the I- } 485 \text { or whose I- } 485 \text { is pending. }\end{array}$} \\
\hline
\end{tabular}

number of pending I-140 applications. This corresponds to the combined third and fourth subsets of the population. The third, the number of pending I-485 applications, corresponds to the combined fourth and sixth subsets. Finally, the number of approved I-140s corresponds to the combined fifth and sixth subsets.

The three rightmost columns of Table 3 present alternative estimation strategies. We make the simplifying assumption that there are no multiple filings. Accordingly, an individual can be found in only one of the six subsets. In the table, one "Y" denotes that the subset is represented, and two "Y"s indicate double-counting of the subset.

Note, however, that there does not seem to be any information on the second subset - those whose labor certification has been approved but whose I-140 is not yet filed. This subset is likely to be small, as most visa applicants (or their petitioners) are thought to file the I-140 as soon as 
the labor certification is obtained. Moreover, since July 2007, labor certifications expire 180 days from the date of certification.

Of course, the sources of information have to be adjusted so that they pertain to our population of interest. Specifically, the labor certification and I-140 figures have to be deflated for non-U.S.-resident applicants, and the I-485 figures have to be deflated for nonprincipals.

We now consider three possible estimation strategies.

1. Estimation using the pending labor certifications and pending I-485s. Suppose we sum, on the same day, the pending labor certification applications and the pending I-485 applications, appropriately deflated for non-U.S.-residents and nonprincipals, respectively. This procedure misses the third and fifth subsets: non-concurrent filers, whose I-140 may be pending or approved and who have not yet submitted the I-485. Thus, this procedure produces an underestimate of principals waiting for adjudication of their applications for employment-based visas.

2. Estimation using the pending labor certifications, pending I-140s, and pending I-485s. Suppose we sum, again on the same day, the pending labor certification applications, the pending I-140 applications, and the pending I-485 applications, all appropriately deflated, the first two for non-U.S.-residents and the last for nonprincipals. As shown in Table 3, this procedure double-counts the fourth subset (concurrent filers whose I-140 and I-485 are both pending) and misses the fifth subset (those whose I-140 is approved and have not filed the I-485).

3. Estimation using the pending labor certifications, pending I-140s, and approved I-140s. Here we sum, again on the same day and appropriately deflated, the pending labor certification applications, the pending I-140 applications, and the number of persons with approved I-140s who have not yet filed the I- 485 or whose I- 485 is pending. This procedure, as shown in Table 3, captures five of the six subsets and does not double-count any subset. It thus appears to be the procedure of choice.

Finally, we note again that other estimation strategies are possible. For example, if the State Department reinstated the annual count of applicants with approved I-140s waiting for numerically limited visas to become available in order to file the I- 485 and if USCIS generated the 
pending totals for I-485s filed after approval of the I-140, these two sets of figures could be used to estimate the fifth and sixth subsets (see Table 3). These estimates could then be compared with those obtained below.

\section{NUMERICAL ESTIMATES}

The preferred strategy for estimating the number of employment principals who have a priority date and are in the United States waiting for LPR (rightmost column of Table 3), given currently available sources of information, has three components: (1) the number of pending labor certification applications; (2) the number of pending I-140 applications; and (3) the number of persons with approved I-140 applications whose I-485 is unfiled or pending. To implement this estimation strategy we estimate the three components for the same time period and, because the first two components pertain to both adjustees and new arrivals, we then remove the new arrivals. ${ }^{11}$ Finally, we also estimate the total number in the employment-based pre-LPR population including family members.

As will be seen below, estimation of the number of persons with approved I-140 applications who are in the population requires information on the number who actually are admitted to LPR each year. This information is published annually by the INS/USCIS. Information on both pending and approved I-140s is available from the USCIS Performance Analysis System (PAS) and published in the U.S. CIS Ombudsman (2007:113-114) report. As of this writing, the PAS data are available for the period 1992-2006. Accordingly, we estimate the employment-based pre-LPR population as of the end of FY 2006.

\section{Components of the Estimates}

Labor Certification Pending Applications. The number of pending labor certification applications has two components, the first pertaining to pending applications in the pre-automated backlog and the second pertaining to pending applications in the automated Permanent Labor Certification

\footnotetext{
${ }^{11}$ Note, however, that, as noted above, some new arrivals are persons who are living in the United States and choose consular processing over USCIS processing (a choice made on the I-140 form but not a permanently binding choice).
} 
Program (PERM) system established in 2005. To estimate the two components, we use the annual performance reports started in FY 2006.

Both the 2006 and 2007 reports state that the backlog of pre-PERM cases numbered about 363,000 (DOL, 2006:5; DOL, 2007:6). The 2006 report further states that 54 percent of the cases had been completed by September 28, 2006 (DOL, 2006:5). Thus, we estimate the number pending in the pre-PERM backlog at the end of FY 2006 at 46 percent of 363,000 , or 166,980 .

The 2006 performance report also gives the number of PERM cases pending at the end of FY 2006. That number is 17,565 (DOL, 2006:7).

Accordingly, we approximate the number of labor certification applications pending at the end of FY 2006 at 184,545 $(166,980+17,565)$.

\section{I-140 Pending Applications. The USCIS Performance Analysis System} provides a time series of the number of I-140 applications pending worldwide at the end of each fiscal year since 1992 (when the provisions of the Immigration Act of 1990 took effect). This time series, along with other PAS figures, is published in U.S. CIS Ombudsman (2007:113-114). The number pending at the end of the fiscal year began a steep climb after 1997, and since 2002 reflects the two countervailing forces of aggressive backlog reduction and increased demand.

The number of pending I-140 applications at the end of FY 2006 is 50,132 . This number represents the combined third and fourth subsets of the pre-LPR population, as shown in Table 3.

Persons With Approved I-140 Applications and Unfled or Pending I-485 Applications. The number of persons, at the end of a fiscal year, with approved I-140 applications who either have not yet filed the I-485 (presumably because a visa number is not available) or whose I-485 is pending is equal to the number at the start of the year plus the number of new I-140 approvals during the year minus the number who became LPR or left the LPR queue (because they died, became discouraged by the wait, or achieved LPR by another route).

As noted above, new I-140 approvals are reported by the PAS system, and new LPRs are reported annually by USCIS. The number of deaths is likely to be small, as this is a prime-age and healthy population. There is no information on the number who get discouraged waiting for a visa number and leave the queue nor is there information on the number who switch pathways to LPR - though the anecdotal evidence is that 
some get discouraged and leave and others switch to courtship and marriage to gain $\mathrm{LPR}$.

Additionally, we have to estimate the number of principals with approved I-140 applications at the start of the first year - 1992. Accordingly, our procedure for estimating the number of principals with approved I-140 applications and either unfiled or pending I-485s has four steps.

First, we estimate the number at the start of the period using the visa waiting lists published by the State Department until 1997. In the context of employment-based visas, the waiting lists cover all principals worldwide with approved I-140 petitions who have not filed the I-485 because a visa number is not available, plus their spouses and children, as of the first of each calendar year (i.e., the fifth subset in Table 3). Accordingly, we use the visa waiting list figures for January $1992-3$ months after the start of FY 1992. The visa queues were: EB-1, 535; EB-2, 32,452; EB-3 skilled, 50,003; and EB-3, "other workers," 87,806. To deflate these figures for nonprincipals, we calculate for each category/subcategory the ratio of family members to principals among new LPRs in FY 1992: EB-1, 1.69; EB-2, 1.12; EB-3 skilled, 1.35; and EB-3 "other workers," 1.40. This procedure yields an estimate of 73,394 principals with approved I-140s who had not filed for the I-485 in January 1992. The number of principals with approved I-140s and pending I-485s at the start of FY 1992 is left unmeasured; it is likely to have been small, as immigration and consular officers expanded their efforts to clear applications under the pre-1992 immigration law (U.S. Department of State, 1992).

Second, we calculate for each year in the period 1992-2006 the number of new approved I-140 petitions minus the number of new LPR principals in EB-1, EB-2, and EB-3 for whom the I-140 is required.

Third, we calculate the running sum of approved I-140s minus LPR principals plus the initial number at the start of the period $(73,394)$. Except for a dip in 2005, the number has increased steadily since 1992. At the end of FY 2006, the number of employment principals with approved I-140 applications and unfiled or pending I-485s is estimated at $327,556 .^{12}$

\footnotetext{
${ }^{12}$ If we omit the number at the start of the period, the running sum at the end of FY 2006 is equal to the sum of all approved I-140s over the 15-year period minus the sum of all the employment principal LPRs during the period $(1,035,567-781,405=254,162)$. Of course, this number plus 73,394 equals the adjusted estimate of 327,556 .
} 
Fourth, we examine the time series and consider whether it should be adjusted downward to reflect the unmeasured departures from the LPR queue. As discussed above, departures would be in the form of deaths (likely to be negligible), persons discouraged by the long wait, and immigrants switching visa category. The visa waiting lists compiled annually by the State Department in the period 1992-1997 (none was compiled for 1996) indicate that the number of "other workers" and their families with approved I-140s and waiting for numerically limited visas was 87,806 in 1992 , climbed to 95,362 in 1993 , and subsequently decreased steeply, to 78,946 in 1995 and to 21,834 in 1997 . These were years when the ceiling for this category was 10,000 and the average number of LPRs was 9,454. As noted in the visa waiting list (U.S. Department of State, 1997), "The Other Worker applicant total has dropped considerably over the past year, perhaps because the long (currently about seven year) wait for a visa has helped to discourage new cases and has given persons previously registered time to reconsider their employment and immigration plans." Moreover, the number of LPRs in the "other workers" subcategory of EB-3 declined further after 1997, reaching 5,001 in 1999 and never again going above 5,000 - due to the new provision of immigration law by which a portion of legalizations under NACARA would be offset by taking numbers from this subcategory.

Thus, a nontrivial number of prospective immigrants in the EB-3 "other worker" subcategory disappeared from the employment-based LPR queue. Where did they go? Consistent with the Jasso, Rosenzweig, and Smith (2000) analysis, some applicants may have switched categories, immigrating via NACARA or by marrying a U.S. citizen, for example. Accordingly, our estimate of the employment pre-LPR queue needs to be adjusted downwards. If the ceiling of 10,000 was reached each year, the unexplained decrease between 1994 and 1997 was 42,514, reflecting approximately 17,733 principals.

Finally, we adjust our initial estimate of 327,556 employment principals with approved I-140 applications and unfiled or pending I-485s at the end of FY 2006 downward (subtracting 17,733) to 309,823. This number represents the combined fifth and sixth subsets of the pre-LPR population, as shown in Table $3 .^{13}$

\footnotetext{
${ }^{13}$ If the unexplained decrease is based on actual LPRs rather than the ceiling of 10,000, the unexplained decrease totals 18,098 principals, which differs only trivially from the 17,733 calculated above.
} 


\section{Estimating the Employment-Based Pre-LPR Population}

In the preceding section, we presented estimates of each of the three components used in the preferred estimation strategy described earlier (shown in the rightmost column of Table 3). We now sum the three components to obtain the worldwide estimate for the end of FY 2006: 184,545 with pending labor certifications (the first subset) plus 50,132 with pending I-140 applications (the third and fourth subsets) plus 309,823 with approved I-140 applications and unfiled or pending I-485 applications (the fifth and sixth subsets) equals 544,500. This is the estimated total number of employment principals in the pre-LPR queue worldwide.

Next we disaggregate the worldwide principals into new arrivals and adjustees. The proportion adjustee among EB-1, EB-2, and EB-3 principals was approximately 91.8 percent in FY 2005. Applying this figure, we obtain an estimate of the number of employment principals waiting for LPR in the United States of approximately 499,680. ${ }^{14}$

To estimate the total number of employment-based prospective immigrants waiting for LPR in the United States, we approximate and add family members. In FY 2005 the ratio of nonprincipals to principals among employment-based adjustees was 1.11. Using this ratio, we obtain an estimate of the entire employment-based pre-LPR queue in the U.S. of $1,056,221$.

Similarly, to estimate the family members of the new-arrival employment principals, we apply the ratio of nonprincipals to principals among new-arrival employment immigrants in FY 2005 (1.83). This procedure yields an estimate of 126,793 prospective new-arrival employment-based immigrants, including both principals and family members. ${ }^{15}$

The corresponding estimate for the worldwide total is $1,183,014$.

Table 4 summarizes our estimates for the employment-based preLPR population, as of the end of FY 2006. The table provides a handy way to see at a glance the number of employment-based persons in the

\footnotetext{
${ }^{14}$ All approximations are based on calculations with unrounded numbers.

${ }^{15}$ If the adjustee-specific and new-arrival-specific ratios of family members to principals vary across EB-1, EB-2, and EB-3 and if the proportions in each visa type in the queue differ from the proportions among new LPRs (if, for example, denial rates differ across visa type), then these ratios of 1.11 and 1.83 yield less than accurate estimates. More accurate estimates would require substantially more precise information on pending I-140s and $\mathrm{I}-485 \mathrm{~s}$ than is currently available. There is no substitute for an improved case management system.
} 
TABLE 4

Estimated Employment-Based Pre-LPR Population at the End of FY 2006

\begin{tabular}{|c|c|c|c|}
\hline & Resident in the U.S. & Resident abroad & Worldwide \\
\hline Principals & 499,680 & 44,820 & 544,500 \\
\hline Family members & 556,541 & 81,973 & 638,514 \\
\hline Total & $1,056,221$ & 126,793 & $1,183,014$ \\
\hline \multicolumn{4}{|c|}{$\begin{array}{l}\text { Notes: As described in the text, summing the estimates of the pending labor certifications, the pending I- } 140 \text { appli- } \\
\text { cations, and the approved I-140 applications with unfiled or pending I- } 485 \text { s yields the worldwide estimate of } \\
\text { principals: } 544,500 \text {. Using the FY } 2005 \text { proportion adjustee }(91.8 \%) \text { yields the estimates of principals resi- } \\
\text { dent in the United States and resident abroad. Using the FY } 2005 \text { ratio of nonprincipals to principals } \\
\text { among employment-based adjustees }(1.11) \text { and new arrivals (1.83) yields the estimates of family members } \\
\text { and hence the total estimates. }\end{array}$} \\
\hline
\end{tabular}

pre-LPR queue, with or without family members and whether living in the United States or abroad.

Reviewing the main features of these estimates, we note that: (1) the estimates assume that there is no double filing of applications; (2) they leave unmeasured the subset with an approved labor certification application who have not yet filed the I-140 and the number who die while in the queue; (3) they also leave unmeasured the fraction who may have left the queue after 1997, either because they were discouraged or because they switched pathways to LPR; and (4) the estimates of the U.S.-resident pre-LPR queue are based on adjustees, but some new arrivals are already living in the United States and choose consular processing for their immigration case. Thus, some of our procedures overestimate and some underestimate the size of the pre-LPR highly skilled population, with an unclear effect on the final magnitude in the pre-LPR queue.

Moreover, recall that at each step in the employment-based LPR process there are denials. Thus, the number of future LPRs is less than the number in the pre-LPR queue.

\section{DISCUSSION}

Our estimates indicate that on October 1, 2006 there were almost half a million foreign-born persons in the United States waiting to adjust to LPR as principals in the first three employment categories, that the total in the U.S. including family members was over a million, and that the total worldwide was almost 1.2 million. Thus, over a million persons were in line for 120,120 visas a year (plus visas not used in the family preferences) - implying that the United States had mortgaged 8-10 years worth of employment visas. 
If all visa processing backlogs were eliminated, approximately 120,120 persons would receive EB-1, EB-2, and EB-3 visas within a year (plus an additional number of persons if visas were not used in the family preferences). The others would experience visa number wait, remaining in the pre-LPR queue as they wait for visas to become available. Those who had filed the I-485 before the processing backlogs were eliminated would be in a kind of semi-halcyon time. They would have a possibly long wait to LPR, but they would retain their employment authorization and travel benefits, based on pending adjustment of status. Those who had not filed the I-485 would have to continue to rely on a succession of temporary work visas.

The lesson is that the employment-based pre-LPR queue includes not only adjustee applicants waiting for adjudication of I-485s and experiencing visa processing wait but also visa applicants stranded at the I-140 stage and experiencing visa number wait because there are not enough employment-based visas. None in this latter set can make the transition to LPR no matter how efficient the Department of Labor and USCIS become at visa processing. Relief would come, not from more backlog elimination and timely processing at DOL and USCIS, but rather from larger allotments of employment visas - something which only Congress can provide.

An important feature of immigration to the United States is that many skilled immigrants acquire legal permanent residence with visas other than employment visas. Data from the New Immigrant Survey indicate that while employment visa categories are the dominant pathway to LPR for the subset adjusting from $\mathrm{H}-1 \mathrm{~B}$ visas (71.2\%), the dominant pathway to LPR for those adjusting from F1 or who were ever an international student is the spouse-of-US-citizen visa, with 79 percent of the F1 adjustees and 59 percent of those who were ever international students using this visa. These figures suggest that international students are attractive marriage prospects and thus have avenues other than employment visas for remaining in the United States. Note that U.S. citizens may be superior to employers in screening future citizens, as they are thinking of the long term rather than the short term (Jasso and Rosenzweig, 1995).

In conclusion, the estimates in this paper present a picture of a large U.S.-resident employment-based pre-LPR population queued up for a long period to obtain permanent residence. While advances in the data systems of the Departments of Homeland Security, Labor, and State together with transparent publication of statistics - would surely yield more accurate estimates of the population and render future estimation 
exercises unnecessary, they would at most modify but not change our main finding. As of the end of FY 2006 there were about half a million employment principals awaiting LPR in the United States, and over half a million family members. The 120,120 visas available annually, or even 150,000 when family preference visas are left unused, are no match for over a million persons in line. The implication is that what has often been seen as a visa processing problem is actually a visa number problem. If flowers are to be sent, they should be sent to Congress, not to USCIS.

Simply recognizing that the problem is a visa number problem rather than a visa processing problem suggests one possible policy response: to let some of the time spent waiting for a visa number count toward naturalization. There is precedent for this in refugee procedures, and it could be a way of saying to visa applicants that the long wait has not been in vain.

Hopefully, our exercise will encourage the government to develop and provide better information on the number of persons with applications of different types pending. Such information would make it possible to track and analyze fluctuations in the pre-LPR queue and enable the government and citizens to assess potential ways to improve the immigration process.

\section{REFERENCES}

Bernstein, N.

2007 "A Floral Protest Over Job-Based Visas." The New York Times, July 11, 2007.

Jasso, G., and M. R. Rosenzweig

1995 "Do Immigrants Screened for Skills Do Better Than Family-Reunification Immigrants?” International Migration Review 29:85-111.

$\longrightarrow$, and J. P. Smith

2000 "The Changing Skill of New Immigrants to the United States: Recent Trends and Their Determinants." In Issues in the Economics of Immigration. Ed. G. J. Borjas. Chicago IL: University of Chicago Press. Pp. 185-225.

Monger, R., and N. Rytina.

2009 "U.S. Legal Permanent Residents: 2008." Annual Flow Report, March 2009. U.S. Department of Homeland Security, Office of Immigration Statistics.

The Triennial Comprehensive Report on Immigration.

1999 Washington, DC: Government Printing Office.

U.S. CIS Ombudsman.

2007 Annual Report to Congress June 2007.

U.S. Department of Homeland Security.

2002-2008 Yearbook of Immigration Statistics. Washington, DC: Government Printing Office. 
U.S. Department of Labor.

2006 "Foreign Labor Certification: International Talent Helping Meet Employer Demand." Performance Report: March 28, 2005 - September 30, 2006. Washington, DC: Office of Foreign Labor Certification.

2007 "Foreign Labor Certification: International Talent Helping Meet Employer Demand.” Performance Report: October 1, 2006 - September 30, 2007. Washington, DC: Office of Foreign Labor Certification.

U.S. Department of State

Various issues "Visa Bulletin." Posted online.

U.S. General Accounting Office.

1989 Immigration Reform: Major Changes Likely Under S. 358. GAO/PEMD-90-5. Washington, DC: U.S. Government Printing Office.

U.S. Immigration and Naturalization Service.

1943-1978 Annual Report of the Immigration and Naturalization Service. Washington, DC: U.S. Government Printing Office.

1979-2001 Statistical Yearbook of the Immigration and Naturalization Service. Washington, DC: Government Printing Office.

U.S. Select Commission on Immigration and Refugee Policy.

1981 U.S. Immigration and the National Interest: Staff Report of the Select Commission on Immigration and Refugee Policy. Issued April 30, 1981. Washington, DC: Government Printing Office.

Warren, R.

2003 "Estimates of the Unauthorized Immigrant Population Residing in the United States: 1990 to 2000." Available at the DHS website. 